\title{
A view of the turf
}

\author{
NICHOLAS COHEN
}

My mother had some curious ideas about education: she brought me up to appreciate a mixture of ballet and horse racing. She gave me the feel that they had something in common: boards and turf, tutus and silks. She was also addicted to the jerky newsreels that were shown in one-hour cinema halls accompanied by the ominous voice of Alvar Lidell. Sometimes we would go to the Empire, Leicester Square, where the Tiller girls flashed a leg illumined by the whirl of organ music and kaleidoscopic lights. At that time I was more interested in the sequins on the costumes than the girls. Anyway I was really waiting for the bark of Lassie or the occasional brief excerpt from a recent horse race on the news. We went only once to a real race course. At Folkestone all my money ended up on a horse running at $25 / 1$, Meltonian, named after the polish on my shoes. The animal came last, bringing me to the first message-the professional never backs intuitively. Intuition may be more fun but that is not what racing is for-or is it ?

Although race courses were not allowed I became friendly with the owners of a fun fair and, under an assumed name, had my first retainer as stable jockey to an old steam merry-go-round, the galloping horses. Faster and faster we went as the punchcard music grinder churned out: "Forever and ever my love shall be thine." Corvo remarks at the start of his study of Hadrian IV that wooden rocking horses cannot shit, but I would swear that these horses could do everything. I never became a jockey because I grew too much and I never became a famous ballet dancer because ... but that is a story my Russian dancing teacher should tell herself.

I mentioned that one should never back intuitively but it must be admitted that I have done so, on occasions. My first real successes came with Nickel Coin and the grey, Nicholas Silver, both horses most people reckoned would never win the Grand National. It was really easy, all things considered, for me to think otherwise. A rather more subtle selection came shortly before my final examination. It was Grand National time again and there was a horse in the field with the appropriate name of Kilmore. The winnings may be reckoned, at least in part, as responsible for my continuing interest in a population-based approach to health.

\section{Four correct Derby winners}

I should reveal, as modestly as is possible in the circumstances, that you are reading the views of a man who has correctly predicted the winners of the last four consecutive Derbys. If there is a single other racing writer with a similar record then he is keeping uncharacteristically quiet. The Minstrel was the first of this batch. Many people, including Richard Baerlein in the Guardian who nears guruhood in my eyes, were put off the Minstrel by his four white socks. But if physiology has taught me anything it is that the melanocytes rarely go more than skin deep. I was more impressed by the acceleration he showed as a two year old in winning the Dewhurst stakes. As a result of the colour prejudice the Minstrel won at 8/1 even with Lester Piggot aboard. Shirley Heights was a more subtle proposition. As often, the judgment came in reading the whole pace of a race correctly-and not only analysing the finish. The key to that Derby was the Dante stakes at York from which I formed the impression that Shirley Heights had plenty in hand over his

\footnotetext{
Centre for International Health and Food Studies, La Fournelaou, Sallagrifion, 06910, France

NICHOLAS COHEN, MD, epidemiologist (present address: PO Box 98, Ramna, Dacca 2, Bangladesh
}

rivals. In the event it turned out to be a nose. Getting the winners of the last two Derbys was rather more difficult. For a start I was mainly in Bangladesh, which has not seen a race horse since Sheikh Mujibur wisely decided there were more important ways of using food. The British Council library saved the day. In between floating down the Brahmaputra I was able to read every newspaper report, though I am sorry to say that my request for airmail copies of Sporting Life was turned down in view of cuts to aid. Eventually a coded cable to my bookmaker was sent out through the US embassy network. Did Washington ever decipher: "CORKTOWN TROY DERBY" ?

Probability theory is of course intimately linked to what is euphemistically called the "investment" side of racing, another reason for me to be grateful to Bradford Hill. More surprisingly perhaps a knowledge of French is a very useful asset. This is simply because punters are strongly chauvinistic. A horse that would start at short odds in England will often be far easier in the market in France, and vice versa. I have paid all expenses twice at the elegant Deauville meeting on this basis. It would have worked out to greater advantage if the sprinter Moorestyle, starting at 13/8 in France as compared with odds-on in the UK, had not been beaten a short-neck (giving away a stone for age). Anyway all losses were recouped, and the theory vindicated, when an Italian filly, ridden I am ashamed to say by a jockey wearing a fetching pair of deep-blue knitted silks which swayed my decision, cantered in at the rewarding odds of 29/1. This made up for losng the telephone number of my bookmaker somewhere in the pine forests of the Alpes Maritimes and therefore only being able to note the name of Henbit, winner of the 1980 Derby, on the back of a chequebook (thus preserved for doubting posterity).

\section{My own racehorse}

I have accepted never becoming a real jockey, but the shape of my legs has not recovered from riding professionally for two years in an African country delivering what it is fashionable to call health care. The horses were Moea (the wind), the miserable Jonah, and Malobe. The health care was all that would fit into a couple of saddle bags and still leave room for me in the saddle. The bags rattled with dental ironmongery used to prize out rotten teeth from villagers in exchange for veteran chickens. Malobe was my own special mount and through him I became a racehorse owner. He had been passed on to me with an evil reputation, having just rolled on the local priest and broken his finger. Still, I got closer to that vild horse than to most wild humans and, to whose credit I am not sure, he threw me only three times. What did emerge also was his exceptional speed.

I trained Malobe for racing on a handy airstrip, but unfortunately he usually swerved off near the huts used for mothers waiting for delivery in the hospital, so we rarely managed more than three furlongs in a straight line. Finally I managed to place him in a village race two days' ride away. We both arrived exhausted, the track was all uphill, and the going literally rock. In addition the local stewards, a group of chiefs at least as powerful on their own terrain as the Jockey Club, forced me to use a local rider in the actual race. Like any self-respecting owner-trainer I have plenty of excuses for my horse coming in a tailed-off last.

I shall probably never own a racehorse again. But as the late monsoon rain swishes outside, I still believe that Sporting Life is a good investment for any institute of public health. How can one hope to form good epidemiologists if they cannot test out their skills on the race track? 